\title{
PENGARUH KEBIJAKAN DIVIDEN DAN PROFITABILITAS TERHADAP NILAI PERUSAHAAN
}

\author{
Marselina H. Umbung ${ }^{1}$, Wehelmina M. Ndoen ${ }^{2}$, Paulina Y. Amtiran ${ }^{3 *}$ \\ ${ }^{1,2,3}$ Universitas Nusa Cendana, selinumbung0601@gmail.com; \\ wehelmina.ndoen@staf.undana.ac.id; \\ paulinaamtiran@staf.undana.ac.id *(Corresponding Author $)$
}

\begin{abstract}
ABSTRAK
Tujuan penelitian ini untuk mengetahui pengaruh kebijakan dividen dan profitabilitas terhadap nilai perusahaan yang berada dalam perusahaan sub sektor tekstil dan garmen yang terdaftar di Bursa Efek Indonesia. Sampel penelitian ini adalah perusahaan manufaktur sub sektor tekstil dan garmen yang terdaftar di Bursa Efek Indonesia (BEI) periode 2014-2018. Data dikumpulkan dengan menggunakan metode dokumentasi. Populasi dalam penelitian ini adalah 22 perusahaan yang berada dalam perusahaan manufaktur sub sektor tekstil dan garment. Pemilihan sampel menggunakan teknik purposive sampling, dengan kriteria sebagai berikut: (1) Perusahaan Manufaktur Sub Sektor Tekstil dan Garmen yang terdaftar di Bursa Efek Indonesia (BEI) periode 2014-2018 yang melakukan kebijakan dividen; (2) Perusahaan yang melaporkan laporan keuangan pada periode 2014-2018; (3) Perusahaan tidak berada dalam kondisi krisis, sehingga diperoleh sampel sebanyak 4 perusahaan. Uji hipotesis dilakukan dengan menggunakan metode analisis regresi data panel (Pooled Data). Hasil penelitian ini menunjukkan: (1) kebijakan dividen berpengaruh positif dan tidak signifikan terhadap nilai perusahaan; (2) profitabilitas berpengaruh positif dan tidak signifikan terhadap nilai perusahaan; (3) kebijakan dividen dan profitabilitas berpengaruh secara simultan terhadap nilai perusahaan; (4) Model pendekatan fixed effect model layak sebagai pengujian model. Melalui penelitian ini dapat memberikan informasi bagi perusahaan untuk dapat mengelola aset dan dana perusahaan untuk meningkatkan nilai perusahaan melalui harga saham serta mampu mengelola aset dan dana yang berasal dari investor secara efektif dan efisien.
\end{abstract}

Kata Kunci: BEI, Kebijakan Dividen, Nilai Perusahaan, Profitabilitas, Tobin's Q

\begin{abstract}
The purpose of this research is to study the effect of dividend policy and profitability on the value of the companies in the textile and garment sub sector companies listed on the Indonesia stock exchange. Data were collected using the documentation method. The sample of this research is the textile and garment manufacturing companies listed on the Indonesia stock exchange (BEI) for the 2014-2018 period. The population in this study is 22 companies in the textile and garment manufacturing sub sector. The sample selection used a purposive sampling technique, with the following criteria 1) Textile and garment sub sector manufacturing companies stock exchange (IDX) for the 2014-2018 period implementing dividend policy; 2) Companies that report financial statements for the 2014-2018 period; 3) The company is not in a crisis condition, so a sample of 4 companies is obtained. Hypothesis testing is performed using panel data regression analysis method (Pooled Data). The result of this study indicate: 1) dividend policy has a positive and insignificant effect on firm value; 2) profitability has a positive and insignificant effect on firm value; 3) dividend and profitability policy have a simultaneous effect on firm value; 4) The fixed effect model approach model is feasible as a model test. The results of this study can provide information for companies to be able to manage company assets and funds to increase company value through stock prices. Through this research, it can provide information for companies to
\end{abstract}


be able to manage company assets and funds to increase company value through stock prices and be able to manage assets and funds from investors effectively and efficiently.

Keywords: BEI, Dividend Policy, Firm Value, Profitability, Tobin'Q

Naskah diterima : 16-08-2021, Naskah dipublikasikan : 30-11-2021

\section{PENDAHULUAN}

Setiap perusahaan didirikan untuk mencapai suatu tujuan tertentu. Tujuan semua perusahaan adalah untuk mencapai keuntungan maksimal, memakmurkan para pemegang saham, dan memaksimalkan nilai perusahaan yang tercermin dari harga sahamnya. Perusahaan dengan prestasi yang lebih baik dibanding perusahaan lain, akan menikmati harga saham yang lebih tinggi dan memperoleh kemudahan untuk menambah dana baru jika diperlukan. Jika dana mengalir ke perusahaan yang memiliki harga saham yang cenderung meningkat, maka sumber-sumber ekonomi akan digunakan dengan cara yang paling efisien (Weston dan Copeland, 2010).

Nilai perusahaan dapat memberikan keuntungan bagi para pemegang saham secara maksimal apabila harga saham meningkat, semakin tinggi harga saham suatu perusahaan maka semakin tinggi juga kemakmuran para pemegang saham. Setiap pemilik perusahaan akan selalu menunjukkan kepada calon investor bahwa perusahaannya layak sebagai alternatif untuk tempat berinvestasi, maka apabila pemilik perusahaan tidak mampu menampilkan sinyal yang baik tentang nilai perusahaan, nilai perusahaan akan berada di atas atau di bawah nilai yang sebenarnya (Sufah dan Riduwan, 2016).

Nilai perusahaan merupakan persepsi investor terhadap tingkat keberhasilan perusahaan yang dikaitkan dengan harga saham. Harga saham yang tinggi membuat nilai perusahaan juga tinggi. Nilai perusahaan yang tinggi akan membuat pasar percaya tidak hanya pada kinerja perusahaan saat ini namun pada prospek perusahaan di masa depan (Wijaya dan Sedana, 2015). Perusahaan harus memperhatikan beberapa hal yang menyebabkan adanya kenaikan nilai perusahaan antara lain kebijakan dividen dan profitabilitas, karena respon investor akan baik jika perusahaan mampu untuk menghasilkan profit dan membagikan dividen (Iswara, 2019).

Menurut Weston dan Brigham (2013) kebijakan dividen adalah mengenai keputusan perusahaan untuk membagikan laba atau menahannya guna diinvestasikan kembali di dalam perusahaan. Kebijakan dividen merupakan bagian yang tidak dapat dipisahkan dengan struktur modal dan keputusan pendanaan perusahaan. Dengan kata lain kebijakan dividen merupakan suatu keputusan pihak manajemen yang menentukan apakah membayar return kepada pemegang saham atau mempertahankan return (perolehan) tersebut untuk diinvestasikan kembali ke dalam perusahaan. Apabila laba perusahaan yang ditahan dalam jumlah besar, berarti laba yang akan dibayarkan sebagai dividen menjadi lebih kecil. Selain itu kebijakan dividen yang optimum merupakan suatu kebijakan yang mempertimbangkan keutamaan semua investor terhadap dividen saat ini dan pertumbuhannya di masa depan yang pada akhirnya dimaksudkan untuk memaksimumkan nilai perusahaan yang dapat ditunjukkan oleh harga saham perusahaan yang bersangkutan Dengan demikian aspek penting dari kebijakan dividen dengan laba yang ditahan di perusahaan (Harjito, 2012).

Profitabilitas merupakan hasil bersih dari serangkaian kebijakan dan keputusan (Bringham dan Houston 2011) yang menjadi daya tarik utama bagi pemegang saham dalam perusahaan (Bringham dan Houston,2011). Dalam konteks ini berarti hasil yang diperoleh melalui usaha manajemen terhadap dana yang diinvestasikan oleh pemegang saham. Profitabilitas juga mencerminkan pembagian laba yang menjadi haknya yaitu seberapa banyak yang diinvestasikan 
kembali dan seberapa banyak yang harus dibayarkan sebagai dividen kepada pemegang saham (Erich, 2003).

Profitabilitas dapat mewakili kondisi keuangan perusahaan, untuk melihat kinerja keuangan terutama laba perusahaan Tingginya profitabilitas perusahaan dapat mempengaruhi nilai perusahaan dan tergantung pada bagaimana persepsi investor terhadap peningkatan profitabilitas perusahaan. Profitabilitas merupakan indikator yang sering digunakan investor untuk melihat nilai dari sebuah perusahaan (Wijaya dan Sedana, 2015).

Penelitian yang dilakukan oleh Ganar (2018) dan Iswara (2019) mengungkapkan bahwa ada kebijakan dividen dan profitabilitas berpengaruh positif dan signifikan terhadap nilai perusahaan dimana semakin tinggi return on asset (ROA) dan dividen payout ratio (DPR) memberikan dampak yang positif terhadap nilai perusahaan. Hal ini mengindikasikan bahwa kinerja perusahaan yang baik akan direspon oleh pasar, yang dapat dilihat melalui peningkatan harga saham. Adanya kebijakan dividen dan profitabilitas diharapkan memberikan dampak yang positif dengan semakin meningkatnya nilai perusahaan.

Di lain pihak penelitian yang dilakukan \{Lestari dan Paryanti (2016); Ilhamsyah dan Soekotjo (2017) ; Kurniasari dan Wahyuati (2017) ; Palupi dan Hendiarto (2018)\} menunjukkan hasil yang berbeda bahwa kebijakan dividen yang diproksikan dengan dividend payout ratio (DPR) secara parsial tidak memiliki pengaruh terhadap nilai perusahaan. Adanya pengaruh dari variabel kebijakan dividen yang dibayarkan kepada pemegang saham meningkat maka nilai perusahaan akan menurun, hal ini dikarenakan semakin tinggi tingkat dividen yang dibayarkan kepada pemegang saham maka semakin sedikit laba yang ditahan dan sebagai akibatnya adalah menghambat tingkat pertumbuhan (rate of growth) dalam pendapatan dan harga sahamnya, sehingga akan menghambat pertumbuhan perusahaan tersebut. Selain itu para pemegang saham lebih menyukai laba yang diperoleh dari capital gain. Hal ini disebabkan untuk memperoleh capital gain dapat diperoleh dengan waktu yang relatif singkat dibandingkan menunggu pembagian dividen yang relatif lama.

Berdasarkan uraian tersebut maka penelitian ini dilakukan untuk mengetahui pengaruh kebijakan dividen dan profitabilitas terhadap nilai perusahaan di perusahaan garmen dan tekstil di Bursa Efek Indonesia dengan menggunakan metode analisis regresi berganda data panel.

\section{KAJIAN LITERATUR}

\section{Kebijakan Dividen}

Menurut Brigham dan Weston (2013) kebijakan dividen adalah mengenai keputusan perusahaan untuk membagikan laba atau menahannya guna diinvestasikan kembali di dalam perusahaan. Ambarwati (2010) mengatakan kebijakan dividen adalah kebijakan yang diambil manajemen perusahaan untuk memutuskan membayarkan sebagian keuntungan perusahaan kepada pemegang saham daripada menahannya sebagai laba ditahan untuk diinvestasikan kepada pemegang saham daripada menahannya sebagai laba ditahan untuk diinvestasikan kembali agar mendapatkan capital gain. Sedangkan menurut Sartono (2010) kebijakan dividen adalah kesempatan investasi yang tersedia, ketersediaan dan biaya modal alternatif, dan preferensi pemegang saham untuk menerima pendapatan saat ini atau menerimanya dimasa mendatang.

Beberapa indikator yang dapat digunakan untuk mengukur kebijakan dividen menurut Fahmi (2012) antara lain : a) dividend yield merupakan rasio yang menghubungkan dividen yang dibayar dengan harga saham biasa perusahaan, dan b) dividend payout ratio merupakan hasil perbandingan antara dividen dengan laba yang tersedia bagi pemegang saham biasa. 


\section{Teori-Teori Kebijakan Dividen}

\section{Teori Ketidakrelevan (Dividend Irrelevance Teory) dari Modigliani dan Miller}

Teori ketidakrelevan dividen (dividend irrelevance teory) adalah teori yang menyatakan bahwa kebijakan dividen perusahaan tidak mempunyai pengaruh baik terhadap nilai perusahaan maupun biaya modal (Brigham \& Weston, 2013).

Penganjur utama teori ini ketidakrelevan dividen (dividend irrelevance teory) adalah Merton Miller dan Franco Modigliani (MM). Mereka berpendapat bahwa nilai perusahaan hanya ditentukan oleh kemampuan dasarnya untuk menghasilkan laba serta risiko bisnisnya. Dengan kata lain Modigliani dan Miller (1961), berpendapat bahwa nilai suatu perusahaan tergantung semata-mata pada pendapatan yang dihasilkan oleh aktivanya, bukan pada bagaimana pendapatan tersebut dibagi di antara dividen dan laba yang ditahan (pertumbuhan).

\section{Teori Dividen yang Relevan (The Bird in the Hand) dari Gordon dan Lintner.}

Teori ini menyatakan bahwa biaya modal sendiri perusahaan akan naik jika persentase laba yang dibayarkan kepada pemegang saham dalam bentuk uang tunai atau DPR (Dividend Payout Ratio) rendah, karena investor lebih suka menerima dividen dari pada perolehan modal (capital gains). Investor memandang keuntungan dividen (dividend yield) lebih pasti daripada keuntungan capital gains. Perlu diingat bahwa dilihat dari sisi investor, biaya modal sendiri dari laba ditahan adalah tingkat keuntungan yang disyaratkan investor pada saham. Laba ditahan adalah keuntungan dari dividen (dividend yield) ditambah keuntungan dari capital gains (capital gains yield).

Modigliani dan Miller (1961) menganggap bahwa argumen Gordon dan Lintner (1963) ini merupakan suatu kesalahan (MM menggunakan istilah "The Bierd in the hand Fallacy"). Menurut MM, pada akhirnya investor akan kembali menginvestasikan dividen yang diterima pada perusahaan yang sama atau perusahaan yang memiliki risiko yang hampir sama (Weston dkk, 2006).

\section{Teori Signaling Hypothesis}

Teori Signaling Hypothesis merupakan teori yang menyatakan bahwa investor menganggap perubahan dividen sebagai pertanda bagi perkiraan manajemen atas laba. Apabila para investor mengharapkan dividen perusahaan naik sebesar 5 persen per tahun, dan apabila dividen tersebut pada kenyataanya naik sebesar 5 persen maka harga saham biasanya tidak banyak berubah pada hari diumumkannya kenaikan dividen. Dalam bahasa Wall Street, kenaikan dividen yang demikian akan didiskonto atau diantisipasi oleh bursa. Akan tetapi jika investor mengharapkan suatu kenaikan 5 persen tetapi perusahaan pada kenyataannya mengalami kenaikan dividen sebesar 25 persen, hal ini biasanya akan disertai dengan suatu kenaikan saham. Sebaliknya kenaikan dividen yang lebih kecil daripada diharapkan, atau suatu penurunan biasanya akan mengakibatkan turunya harga.

Kenyataannya bahwa kenaikan dividen yang besar biasanya menyebabkan kenaikan harga saham memberi kesan bagi sementara orang bahwa investor secara keseluruhan lebih menyukai dividen ketimbang kenaikan nilai modal. Akan tetapi Merton Miller dan Franco Modigliani (MM) berpendapat lain. Mereka memperhatikan adanya fakta yang cukup kuat bahwa perusahaan selalu enggan menurunkan dividen akibatnya manajer tidak akan menaikkan kecuali kalau manajer mengantisipasi laba yang lebih tinggi, atau sekurang-kurangnya laba yang stabil di masa mendatang. 
Oleh karena itu menurut Miller dan Modigliani (MM) ini berarti bahwa suatu kenaikan dividen lebih besar daripada yang diperkirakan merupakan "sinyal" bagi investor bahwa manajemen perusahaan memperkirakan peningkatan laba di masa mendatang sedangkan penurunan dividen menandakan perkiraan laba yang rendah atau buruk. Jadi, Miller dan Modigliani (MM) menegaskan bahwa reaksi investor terhadap perubahan dalam pembagian dividen tidak menunjukkan bahwa investor lebih suka dividen daripada laba ditahan, perubahan harga saham hanya menunjukkan bahwa informasi penting terkandung di dalam pengumuman dividen.

\section{Profitabilitas}

Menurut Brigham dan Houston (2011) profitabilitas adalah hasil bersih dari serangkaian kebijakan dan keputusan. Menurut Weston dan Copeland (2010) profitabilitas merupakan hasil akhir bersih dari berbagai kebijakan dan keputusan. Sartono (2010) mengatakan profitabilitas berkaitan dengan kemampuan perusahaan memperoleh laba dalam hubungannya dengan penjualan, total aktiva maupun modal sendiri. Sedangkan menurut Erich (2003) profitabilitas adalah hasil yang diperoleh melalui usaha manajemen terhadap dana yang diinvestasikan oleh pemilik. Adapun indikator profitabilitas menurut Fahmi (2 012), antara lain : a) Net Profit Margin (NPM) ; b) Return on Investment (ROI) ; c) Return on Equity (ROE) dan d) Gross Profit Margin (GPM).

\section{Nilai Perusahaan}

Menurut Harmono (2014) nilai perusahaan adalah kinerja perusahaan yang dicerminkan oleh harga saham yang dibentuk oleh permintaan dan penawaran pasar modal yang merefleksikan penilaian masyarakat terhadap kinerja perusahaan. Fahmi mengatakan (2012) nilai perusahaan adalah rasio yang menggambarkan kondisi yang terjadi di pasar. Sedangkan menurut Noerirawan (2012) nilai perusahaan adalah kondisi yang telah dicapai oleh suatu perusahaan sebagai gambaran dari kepercayaan masyarakat terhadap perusahaan setelah melalui suatu proses kegiatan selama satu periode. Beberapa indikator yang digunakan untuk nilai perusahaan menurut Fahmi (2012) :

a) Price Earning Ratio (PER) ; Bagi para investor semakin tinggi price earning ratio maka pertumbuhan laba yang diharapkan juga mengalami kenaikan. Dengan begitu price earning ratio adalah perbandingan antara market price per share (harga per lembar saham) dengan earning per share (laba per lembar saham).

b) Tobin's Q Ratio (Q Tobin's) ; Tobin's Q Ratio adalah nilai pasar dari aset perusahan dibagi dengan biaya penggantiannya.

c) Price Book Value (PBV) ; Price Book Value merupakan perbandingan antara harga saham dengan nilai buku. Nilai buku per lembar saham dapat dihitung dengan membandingkan total ekuitas saham biasa dengan jumlah saham beredar. 
Penelitian ini untuk menguji pengaruh kebijakan dividen dan profitabilitas terhadap nilai perusahaan sebagaimana ditunjukkan pada gambar 1 berikut :

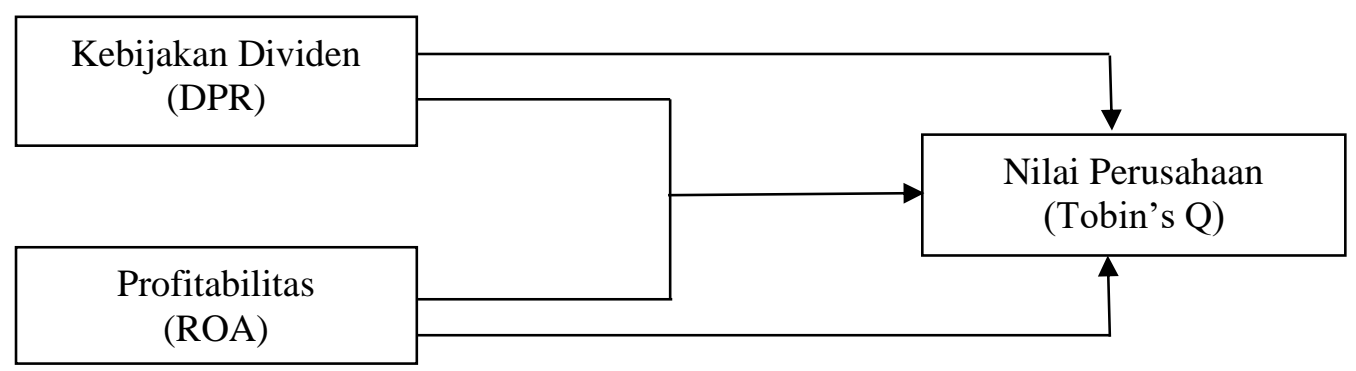

Gambar 1. Kerangka Berpikir

\section{HIPOTESIS PENELITIAN}

Pembagian dividen yang tinggi merupakan salah satu sinyal positif bagi investor untuk melakukan investasi. Dividen yang tinggi dapat meningkatkan harapan investor sehingga secara tidak langsung dapat meningkatkan harga saham (Iswara, 2019). Penelitian Ganar (2018) dan Iswara (2019) mengungkapkan bahwa kebijakan dividen berpengaruh positif terhadap nilai perusahaan.

Profitabilitas merupakan daya tarik utama bagi pemegang saham dalam suatu perusahaan. Tingginya profitabilitas perusahaan dapat mempengaruhi nilai perusahaan dan tergantung pada bagaimana persepsi investor terhadap peningkatan profitabilitas perusahaan. Profitabilitas merupakan indikator yang sering digunakan oleh investor untuk melihat nilai dari suatu perusahaan (Wijaya dan Sedana, 2015). Penelitian yang dilakukan oleh Rahmanto (2017) ; Ilhamsyah dan Soekotjo (2017) mengungkapkan bahwa profitabilitas berpengaruh positif terhadap nilai perusahaan

Berdasarkan uraian di atas, maka penelitian ini menggunakan hipotesis. Hipotesis yang digunakan dalam penelitian ini adalah sebagai berikut:

$\mathrm{H}_{1}$ : Kebijakan dividen berpengaruh positif dan signifikan terhadap nilai perusahaan.

$\mathrm{H}_{2}$ : Profitabilitas berpengaruh positif dan signifikan terhadap nilai perusahaan.

$\mathrm{H}_{3} \quad$ : Kebijakan dividen dan profitabilitas berpengaruh signifikan terhadap nilai perusahaan

\section{METODE PENELITIAN}

\section{Jenis Penelitian}

Pendekatan yang digunakan dalam penelitian ini adalah pendekatan kuantitatif, dimana yang menjadi unit analisisnya adalah perusahaan garmen dan tekstil yang terdaftar di Bursa Efek Indonesia. Data yang digunakan adalah data sekunder yang berupa laporan keuangan perusahaan garment dan tekstil periode 2014-2018 yang diunggah melalui website Bursa Efek Indonesia.

\section{Teknik Pengumpulan Data}

Teknik pengumpulan data melalui studi dokumentasi yang terkait dengan variabel yang digunakan dalam penelitian ini yaitu data perusahaan yang melakukan kebijakan dividen, profitabilitas dan nilai perusahaan yang dipublikasikan di BEI. 


\section{JURNAL AKUNTANSI, Vol. 10, No. 2, November (2021)}

\section{Populasi dan Sampel}

Populasi perusahaan garment dan tekstil di BEI berjumlah 21 perusahaan. Untuk itu digunakan metode sampel untuk memudahkan pengolahan dan analisis data. Metode penentuan sampel dilakukan dengan purposive sampling dengan kriteria sebagai berikut :

a) perusahaan garment dan tekstil yang melakukan kebijakan dividen ;

b) perusahaan garment dan tekstil yang melaporkan laporan keuangan selama periode 20142018 dan ;

c) perusahaan garment dan tekstil yang tidak berada dalam kondisi krisis. Dari metode sampel yang dilakukan maka terdapat 4 perusahaan yang dijadikan sampel dalam penelitian ini, yaitu:

Tabel 1. Sampel Penelitian

\begin{tabular}{clc}
\hline No & \multicolumn{1}{c}{ Nama Perusahaan } & Kode Perusahaan \\
\hline 1 & Sri Rejeki Isman Tbk & SRIL \\
2 & Pan Brothers Tbk & PBRX \\
3 & Ricky Putra Global & RICY \\
4 & Trisula Internasional & TRIS \\
\hline
\end{tabular}

Sumber Data : IDX, 2020

Proksi-proksi yang digunakan dalam penelitian ini adalah :

a) dividend payout ratio untuk kebijakan dividen ;

b) return on assets untuk profitabilitas dan

c) tobin's $Q$ untuk nilai perusahaan.

Teknik analisis data yang digunakan penelitian ini adalah analisis regresi data panel.

\section{HASIL DAN PEMBAHASAN}

\section{Hasil Analisis Statistik Deskriptif}

Hasil deskriptif bertujuan untuk menganalisis data dengan cara mendeskripsikan atau menggambarkan data yang telah terkumpul sebagaimana adanya tanpa membuat kesimpulan yang berlaku untuk umum atau generalisasi. Hasil output dari analisis statistik deskriptif berikut dapat dilihat besarnya nilai minimum, maximum, mean, dan standar deviasi ditunjukkan tabel 2 berikut:

Tabel 2. Analisis Statistik Deskriptif

\begin{tabular}{cccc}
\hline & $\mathrm{X}_{1}$ & $\mathrm{X}_{2}$ & $\mathrm{Y}$ \\
\hline Mean & 0.644000 & 0.036500 & 3.963500 \\
Median & 0.370000 & 0.030000 & 3.075000 \\
Maximum & 2.400000 & 0.070000 & 9.880000 \\
Minimum & 0.100000 & 0.010000 & 0.750000 \\
Std. Dev. & 0.626044 & 0.023902 & 3.365574
\end{tabular}




\begin{tabular}{cccc}
\hline & $\mathrm{X}_{1}$ & $\mathrm{X}_{2}$ & $\mathrm{Y}$ \\
\hline Skewness & 1.350617 & 0.284058 & 0.337368 \\
Kurtosis & 4.208323 & 1.526736 & 1.528851 \\
Jarque-Bera & 7.297263 & 2.077717 & 2.182957 \\
Probability & 0.026027 & 0.353858 & 0.335720 \\
Sum & 12.88000 & 0.730000 & 79.27000 \\
Sum Sq. Dev. & 7.446680 & 0.010855 & 215.2147 \\
Observations & 20 & 20 & 20 \\
\hline
\end{tabular}

Sumber : Hasil Olah Data, 2021

Hasil analisis statistik deskriptif tersebut menginformasikan bahwa nilai perusahaan (Y) manufaktur sub sektor tekstil dan garmen periode 2014-2018 paling rendah sebesar 0.750 dan paling tinggi sebesar 9.880 poin. Rata-rata nilai perusahaan manufaktur sub sektor tekstil dan garmen periode 2014-2018 sebesar 3.963 poin dan standar deviasi sebesar 3.365 poin. Hal ini berarti nilai perusahaan manufaktur sub sektor tekstil dan garmen periode 2014-2018 mean lebih besar dari standar deviasi $3.963>3.365$.

Hasil deskriptif tersebut menginformasikan bahwa DPR $\left(\mathrm{X}_{1}\right)$ pada perusahaan manufaktur sub sektor tekstil dan garmen periode 2014-2018 paling rendah sebesar 0.100 dan paling tinggi sebesar 2.400 poin. Rata-rata DPR pada perusahaan manufaktur sub sektor tekstil dan garmen periode 2014-2018 sebesar 0.644 poin dan standar deviasi sebesar 0.626 poin. Hal ini berarti DPR pada perusahaan manufaktur sub sektor tekstil dan garmen periode 2014-2018 mean lebih besar dari standar deviasi $0.644>0.626$.

Hasil analisis deskriptif tersebut menginformasikan bahwa ROA $\left(\mathrm{X}_{2}\right)$ pada perusahaan manufaktur sub sektor tekstil dan garmen periode 2014-2018 paling rendah sebesar 0.010 dan paling tinggi sebesar 0.070 poin. Rata-rata nilai perusahaan manufaktur sub sektor tekstil dan garmen periode $2014-2018$ sebesar 0.036 poin dan standar deviasi sebesar 0.023 poin. Hal ini berarti ROA pada perusahaan manufaktur sub sektor tekstil dan garmen periode 2014-2018 mean lebih besar dari standar deviasi $0.036>0.023$.

\section{Hasil Analisis Regresi Data Panel}

Analisis regresi data panel dilakukan dengan tiga (3) metode yaitu : (1) common effect model ; (2) fixed effect model dan (3) random effect model. Dari hasil analisis regresi tiga (3) model tersebut regresi data panel dengan fixed effect model merupakan model yang memiliki hasil yang lebih baik dibandingkan dengan common effect model dan random effect model. Hasil analisis regresi data panel dengan fixed effect model ditunjukkan tabel 3 berikut ini :

Tabel 3. Hasil Regresi Data Panel Fixed Effect Model

\begin{tabular}{crrrr}
\hline Variable & Coefficient & Std. Error & t-Statistic & Prob. \\
\hline $\mathrm{C}$ & 2.764072 & 1.230727 & 2.245886 & 0.0414 \\
$\mathrm{X}_{1}$ & 0.671968 & 0.701336 & 0.958126 & 0.3543 \\
$\mathrm{X}_{2}$ & 21.00495 & 27.34311 & 0.768199 & 0.4551 \\
\hline \multicolumn{5}{c}{ Effects Specification } \\
\hline
\end{tabular}




\section{JURNAL AKUNTANSI, Vol. 10, No. 2, November (2021)}

\begin{tabular}{|c|c|c|c|}
\hline Variable & Coefficient & Std. Error & Prob. \\
\hline Root MSE & 1.014979 & R-squared & 0.904265 \\
\hline Mean dependent var & 3.963500 & Adjusted R-squared & 0.870073 \\
\hline S.D. dependent var & 3.365574 & S.E. of regression & 1.213132 \\
\hline Akaike info criterion & 3.467614 & Sum squared resid & 20.60366 \\
\hline Schwarz criterion & 3.766333 & Log likelihood & -28.67614 \\
\hline Hannan-Quinn criter. & 3.525927 & F-statistic & 26.44728 \\
\hline Durbin-Watson stat & 2.650755 & Prob(F-statistic) & 0.000001 \\
\hline
\end{tabular}

Sumber : Hasil Olah Data, 2021

Persamaan hasil regresi data panel dengan fixed effect model dapat dirumuskan sebagai berikut :

$$
\text { Tobin's } \mathrm{Q}=\alpha+\beta_{1} \mathrm{DPR}+\beta_{2} \mathrm{ROA}+\mathrm{e}
$$

Sehingga hasil regresi data panel :

$$
\text { Tobin's } \mathrm{Q}=2,764+0,6719 \mathrm{DPR}+21,004 \mathrm{ROA}
$$

Berdasarkan persamaan tersebut dapat dijelaskan bahwa nilai konstanta sebesar 2,764, artinya jika kebijakan dividen (DPR) dan profitabilitas (ROA) bernilai 0 atau konstan maka nilai perusahaan sebesar 2,764. Nilai DPR sebesar 0,671 artinya jika DPR bertambah 1 satuan maka akan meningkatkan nilai perusahaan sebesar 0,6719. Nilai ROA sebesar 21,004 menjelaskan bahwa jika ROA bertambah 1 satuan maka akan meningkatkan nilai perusahaan sebesar 21,004.

\section{Uji Chow}

Uji Chow digunakan untuk mengetahui apakah teknik regresi data panel fixed effect model dengan common effect model. Hasil uji chow ditunjukkan tabel 4, berikut :

Tabel 4. Hasil Uji Chow

\begin{tabular}{crrr}
\hline Effects Test & Statistic & $d f$. & Prob. \\
\hline Cross-section F & 15.476854 & $(3,14)$ & 0.0001 \\
Cross-section Chi-square & 29.248753 & 3 & 0.0000 \\
& & & \\
\hline
\end{tabular}

Sumber : Hasil Olah Data, 2021

Hasil pengujian uji chow test menunjukkan bahwa nilai probabilitas sebesar $0.000<5 \%$, sehingga $\mathrm{H}_{0}$ ditolak dan menerima $\mathrm{H}_{1}$, maka model estimasi fixed effect model lebih tepat digunakan dibandingkan dengan model estimasi common effect model. 


\section{JURNAL AKUNTANSI, Vol. 10, No. 2, November (2021)}

\section{Uji Hausman}

Uji Hausman digunakan untuk menentukan efek individu dalam model estimasi regresi panel. Hasil uji hausman ditunjukkan tabel 5, berikut :

Tabel 5. Hasil Uji Hausman

\begin{tabular}{cccc}
\hline Test Summary & $\begin{array}{c}\text { Chi-Sq. } \\
\text { Statistic }\end{array}$ & Chi-Sq. d.f. & Prob. \\
\hline Cross-section random & 46.422986 & 2 & 0.0000 \\
\hline
\end{tabular}

Sumber : Hasil Olah Data, 2021

Tabel 5 menunjukkan bahwa nilai yang probabilitas sebesar $0,0000<0,05$ yang berarti intersep untuk semua unit cross section tidak sama, sehingga $\mathrm{H}_{0}$ ditolak dan $\mathrm{H}_{1}$ diterima. Dengan demikian metode estimasi fixed effect model lebih baik digunakan daripada estimasi random effect model.

\section{Koefisien Determinasi $\left(\boldsymbol{R}^{2}\right)$}

Koefisien determinasi $\left(\mathrm{R}^{2}\right)$ dilakukan untuk menguji pengaruh variabel kebijakan dividen dan profitabilitas terhadap nilai perusahaan. Semakin tinggi nilai koefisien determinasi $\left(\mathrm{R}^{2}\right)$, maka semakin besar pengaruh variabel independen terhadap variabel dependen.

Tabel 6. Hasil Koefisien Determinasi Estimasi Fixed Effect Model

\begin{tabular}{cc}
\hline$R$-squared & 0.904265 \\
Adjusted $R$-squared & 0.870073 \\
\hline
\end{tabular}

Sumber : Hasil Olah Data, 2021

Hasil pengujian determinasi estimasi fixed effect model diketahui bahwa nilai Adjusted $R$-squared sebesar 0.870 . Hasil ini menunjukkan bahwa $87 \%$ perubahan nilai perusahaan dipengaruhi oleh kebijakan dividen dan profitabilitas sedangkan sisanya $13 \%$ dijelaskan oleh variabel lain diluar variabel independen yang digunakan dalam penelitian.

\section{Uji t}

Uji t dilakukan untuk menunjukkan pengaruh variabel independen terhadap variabel dependen secara parsial, berikut hasil uji t yang ditunjukkan tabel 6 :

Tabel 7. Hasil Uji t Berdasarkan Fixed Effect Model

\begin{tabular}{crrrr}
\hline Variable & Coefficient & Std. Error & t-Statistic & Prob. \\
\hline $\mathrm{C}$ & 2.764072 & 1.230727 & 2.245886 & 0.0414 \\
$\mathrm{X}_{1}$ & 0.671968 & 0.701336 & 0.958126 & 0.3543 \\
$\mathrm{X}_{2}$ & 21.00495 & 27.34311 & 0.768199 & 0.4551 \\
\hline
\end{tabular}

Sumber : Hasil Olah Data, 2021 
Berdasarkan tabel 5 uji t (fixed effect model) diperoleh nilai kebijakan dividen $\left(\mathrm{X}_{1}\right)$ sebesar $0.354>0.05$. Hal ini berarti bahwa kebijakan dividen berpengaruh positif namun tidak signifikan terhadap nilai perusahaan. Hasil ini menunjukkan bahwa besarnya dividen yang dibagikan perusahaan kepada pemegang saham tidak mempengaruhi nilai perusahaan. Nilai profitabilitas $\left(\mathrm{X}_{2}\right)$ sebesar $0.455>0,05$, menunjukkan bahwa profitabilitas berpengaruh positif namun tidak signifikan terhadap nilai perusahaan. Hal ini dikarenakan periode pengamatan pada subyek penelitian terjadi fluktuasi laba perusahaan dari tahun ke tahun.

\section{Uji F}

Uji F dilakukan untuk menunjukkan pengaruh secara simultan antara variabel independen dan variabel dependen. Berikut hasil uji F yang ditunjukkan oleh tabel 7 berikut :

Tabel 8. Hasil Uji F Berdasarkan Fixed Effect Model

\begin{tabular}{lllr}
\hline Root MSE & 1.014979 & R-squared & 0.904265 \\
$\begin{array}{l}\text { Mean dependent } \\
\text { var }\end{array}$ & 3.963500 & Adjusted R-squared & 0.870073 \\
$\begin{array}{l}\text { S.D. dependent var } \\
\text { Akaike info } \\
\text { criterion }\end{array}$ & 3.365574 & S.E. of regression & 1.213132 \\
Schwarz criterion & 3.467614 & Sum squared resid & 20.60366 \\
$\begin{array}{l}\text { Hannan-Quinn } \\
\text { criter. }\end{array}$ & 3.525927 & F-statistic & - \\
$\begin{array}{l}\text { Durbin-Watson } \\
\text { stat }\end{array}$ & 2.650755 & Prob(F-statistic) & 0.000001 \\
\hline
\end{tabular}

Sumber : Hasil Olah Data, 2021

Hasil uji $\mathrm{F}$ menunjukkan bahwa nilai probabilitas kebijakan dividen $\left(\mathrm{X}_{1}\right)$ dan profitabilitas $\left(\mathrm{X}_{2}\right)$ sebesar $0.000<0,05$. Hal ini berarti bahwa kebijakan dividen dan profitabilitas secara simultan berpengaruh positif dan signifikan terhadap nilai perusahaan.

\section{PEMBAHASAN}

\section{Pengaruh Kebijakan Dividen Terhadap Nilai Perusahaan}

Berdasarkan hasil analisis data dapat dijelaskan bahwa kebijakan dividen berpengaruh positif dan tidak signifikan terhadap nilai perusahaan. Artinya besarnya dividen yang dibagikan oleh perusahaan kepada pemegang saham tidak mempengaruhi nilai perusahaan. Adanya pengaruh tidak signifikan dari variabel kebijakan dividen terhadap nilai perusahaan menunjukkan jika kebijakan dividen yang dibayarkan kepada pemegang saham meningkat maka nilai perusahaan akan menurun, hal ini dikarenakan semakin tinggi tingkat dividen yang dibayarkan maka akan semakin sedikit laba yang ditahan dan sebagai akibatnya adalah menghambat tingkat pertumbuhan (rate of growth) dalam pendapatan dan harga saham, sehingga akan menghambat pertumbuhan perusahaan. Jika tingkat pertumbuhan perusahaan kecil maka hal ini akan dilihat oleh para investor sebagai informasi negatif dari perusahaan sehingga saham dari perusahaan kurang diminati oleh para investor dan akibatnya harga saham akan menurun. Sehingga hal ini akan menyebabkan nilai perusahaan juga akan menurun. 
Hasil dari penelitian ini didukung oleh teori ketidakrelevan (Dividend Irrelevance Teory) yang dikemukakan oleh Modigliani dan Miller yang menyatakan bahwa kebijakan dividen perusahaan tidak mempunyai pengaruh terhadap nilai perusahaan maupun biaya modalnya. Mereka berpendapat bahwa nilai suatu perusahaan hanya ditentukan oleh kemampuan dasarnya untuk menghasilkan laba serta risiko bisnisnya. Dengan kata lain Modigliani dan Miller berpendapat bahwa nilai suatu perusahaan tergantung semata-mata pada pendapatan yang dihasilkan oleh aktivanya, bukan pada bagaimana pendapatan tersebut dibagi di antara dividen dan laba ditahan (Weston dan Brigham, 2006). Hasil penelitian ini sama dengan hasil penelitian yang dilakukan oleh Ilhamsyah (2017), Lestari, Paryanti (2016), Rahmanto (2017), yang menyatakan bahwa kebijakan dividen yang diukur dengan menggunakan dividend payout ratio (DPR) tidak berpengaruh signifikan terhadap nilai perusahaan.

\section{Pengaruh Profitabilitas Terhadap Nilai Perusahaan}

Variabel profitabilitas berpengaruh positif dan tidak signifikan terhadap nilai perusahaan. ROA tidak berpengaruh terhadap nilai perusahaan disebabkan karena pada periode yang menjadi objek penelitian terjadi peningkatan dan penurunan laba perusahaan dari tahun ke tahun yang tidak stabil. Laba yang diperoleh oleh perusahaan setiap periode ada yang mengalami peningkatan ada juga yang mengalami penurunan laba perusahaan. Jika rasio ROA yang rendah para investor tidak akan tertarik menanamkan modalnya terhadap perusahaan, karena jika ROA menurun maka akan diikuti dengan penurunan nilai perusahaan. Hasil penelitian ini sama dengan hasil penelitian dari Kurniasari, Wahyuti (2017), dan Palupi, Hendiarto (2018), yang menyatakan bahwa profitabilitas yang diukur dengan menggunakan return on assets (ROA) tidak berpengaruh signifikan terhadap nilai perusahaan.

\section{Pengaruh Kebijakan Dividen dan Profitabilitas Terhadap Nilai Perusahaan}

Variabel kebijakan dividen dan profitabilitas secara simultan berpengaruh dan signifikan terhadap nilai perusahaan. Hal ini mengindikasikan bahwa setiap perusahaan didirikan untuk mencapai suatu tujuan tertentu. Tujuan semua perusahaan adalah untuk mencapai keuntungan maksimal, memakmurkan para pemegang saham dan memaksimalkan nilai perusahaan yang tercermin dari harga sahamnya. Pembagian dividen dilaksanakan apabila profitabilitas atau laba yang diperoleh oleh perusahaan dalam satu periode tertentu menghasilkan laba yang maksimal. Profitabilitas yang dihasilkan oleh perusahaan dalam satu periode tertentu tidak maksimal maka pembagian dividen tidak boleh dilaksanakan. Apabila pembagian dividen tetap dilaksanakan sebagai akibatnya adalah menghambat tingkat pertumbuhan perusahaan. Laba yang tidak dibagikan dalam bentuk dividen tersebut akan lebih baik disimpan sebagai dana cadangan apabila perusahaan membutuhkan dana lebih dalam melakukan kegiatannya. Kebijakan dividen dan profitabilitas dalam suatu perusahaan harus berjalan seimbang sehingga dapat mempengaruhi nilai perusahaan kearah yang lebih baik.

Hasil penelitian ini sesuai dengan penelitian sebelumnya yang dilakukan oleh Ganar (2018), dan Iswara (2019), yang menyatakan bahwa kebijakan dividen yang diukur dengan menggunakan dividend payout ratio (DPR) dan profitabilitas yang diukur menggunakan return on assets (ROA) yang menyatakan bahwa hasil dari uji $\mathrm{F}$ atau uji simultannya di pengaruhi secara bersama-sama terhadap nilai perusahaan. 


\section{PENUTUP}

\section{Simpulan}

Variabel kebijakan dividen yang diukur dengan menggunakan dividend payout ratio (DPR) tidak berpengaruh terhadap nilai perusahaan. Jika kebijakan dividen yang dibayarkan kepada pemegang saham meningkat maka nilai perusahaan akan menurun, hal ini dikarenakan semakin tinggi tingkat dividen yang dibayarkan maka akan semakin sedikit laba yang ditahan dan sebagai akibatnya adalah menghambat tingkat pertumbuhan (rate of growth) dalam pendapatan dan harga saham, sehingga akan menghambat pertumbuhan perusahaan. Dari hasil penelitian menggunakan analisis regresi panel tidak sesuai atau tidak terbukti dengan hipotesis, bahwa kebijakan dividen berpengaruh positif dan signifikan terhadap nilai perusahaan.

Variabel profitabilitas yang diukur dengan menggunakan return on assets (ROA) tidak berpengaruh terhadap nilai perusahaan. Jika rasio ROA yang rendah para investor tidak akan tertarik menanamkan modalnya terhadap perusahaan, karena jika ROA menurun maka akan diikuti dengan penurunan nilai perusahaan. Dari hasil penelitian dengan menggunakan analisis regresi panel tidak sesuai atau tidak terbukti dengan hipotesis, bahwa profitabilitas berpengaruh positif dan signifikan terhadap nilai perusahaan. Berdasarkan hasil analisis regresi data panel, bahwa kebijakan dividen dan profitabilitas secara simultan berpengaruh signifikan terhadap nilai perusahaan. Model regresi panel yang tepat digunakan dalam penelitian ini yaitu fixed effect model.

Implikasi penelitian ini dapat memberikan informasi bagi perusahaan untuk dapat mengelola aset dan dana perusahaan untuk meningkatkan nilai perusahaan melalui harga saham serta mampu mengelola aset dan dana yang berasal dari investor secara efektif dan efisien.

\section{Saran}

Bagi para investor sebaiknya memperhitungkan beberapa aspek penting dalam berinvestasi serta menggunakan rasio keuangan yang tepat agar investasi yang dilakukan mendapatkan profit yang maksimal dan investor tidak merasa dirugikan.

Bagi manajemen perusahaan diharapkan untuk meningkatkan kepercayaan para investor terhadap perusahaan, maka perusahaan harus menunjukkan kinerja yang baik. Manajemen perusahaan juga untuk meningkatkan nilai perusahaan melalui harga saham perusahaan di pasar modal, maka perusahaan harus mampu mengelola aset dan dana yang berasal dari investor secara efektif dan efisien.

Penelitian selanjutnya diharapkan menggunakan sampel yang berbeda dan menambahkan pengaruh variabel-variabel lainnya seperti ukuran perusahaan, kebijakan utang, keputusan investasi agar diperoleh hasil yang lebih baik dan lebih akurat dan dapat dijadikan dasar prediksi faktor-faktor yang mempengaruhi nilai perusahaan.

\section{REFERENSI}

Agus, Sartono. 2010. Manajemen Keuangan: Teori dan Aplikasi. Edisi Keempat. Yogyakarta: BPFE.

Ambarwati, A.D.S. 2010. Manajemen Keuangan Lanjutan. Cetakan pertama, Penerbit : Graha Ilmu: Yogyakarta

Brigham, dan Houston. 2011. Dasar-dasar Manajemen Keuangan, Edisi Sepuluh,. Penerbit Salemba Empat, Jilid I, Jakarta. 
Basuki T. Agus dan Prawoto Nano. 2016. Analisis Regresi Dalam Penelitian Ekonomi Dan Bisnis: Dilengkapi Aplikasi SPSS Dan Eviews. Raja Grafindo Persada, Jakarta.

Erich A. Helfert, D.B.A, 2003, Analisis Laporan Keuangan, Edisi Ketujuh, Penerbit Erlangga. Jakarta.

Fahmi, Irham. 2018. Pengantar Manajemen Keuangan: Teori dan Aplikasi. Penerbit CV Alfabeta, Bandung.

Ganar, Y. B. 2018. Pengaruh Kebijakan Dividen Dan Profitabilitas Terhadap Nilai Perusahaan Pada Perusahaan Yang Terdaftar Di Bursa Efek Indonesia Periode 2013- 2017. E. Jurnal Sekuritas, ISSN: 2581-2777 \& ISSN: 2581-2696. (http://openjournal.unpam.ac.id)

Ghozali, Imam. 2013. Aplikasi Analisis Multivariate Dengan Program IBM SPSS 19. Semarang: Badan Penerbit Universitas Diponegoro.

Harjito, Agus. 2012. Dasar-dasar Teori Keuangan. Yogyakarta: Penerbit Ekonista.

Harmono, 2014. Manajemen Keuangan. Edisi Pertama. Bumi Aksara, Jakarta.

Ilhamsyah, L.F, Soekotjo,H. 2017. Pengaruh Kebijakan Dividen, Keputusan Investasi, Dan Profitabilitas Terhadap Nilai Perusahaan. Jurnal Ilmu dan Riset Manajemen Volume 6, Nomor 2, Tahun 2017. e-ISSN : 2461-0593. (http://jurnal mahasiswa.stiesia.ac.id).

Iswara, U. S. 2019. Pengaruh Kebijakan Dividen Dan Profitabilitas Terhadap Nilai Perusahaan Pada Industri Barang Konsumsi Terdaftar Di Bursa Efek Indonesia. E. Jurnal Fintech dan E-Commerce untuk mendorong pertumbuhan UMKM dan industri kreatif. (https://jurnal.untidar.ac.id).

Kurniasari M., P., Wahyuati A. 2017, Pengaruh profitabilitas rasio aktivitas dan leverage terhadap nilai perusahaan manufaktur di BEI. Jurnal Ilmu dan Riset Manajemen, Vol 6 No.8, 2017. e-ISSN:2461-0593. (https://Jurnal Mahasiswa.Stiesia.ac.id).

Lestari, S., \& Paryanti, A.B. 2016. Pengaruh Profitabilitas Dan Kebijakan Dividen Terhadap Nilai Perusahaan Pada Perusahaan Perbankan Yang Terdaftar Di BEI tahun 2006-2010. E. Jurnal CKI On SPOT, Vol. 9, No. 1, $2016 . \quad$ ISSN 1979-7044. (https://jurnal.stikomcki.ac.id).

Noerirawan, M.R. 2012. Pengaruh Faktor Internal Dan Eksternal Perusahaan Terhadap nilai Perusahaan. Skripsi. Semarang. Fakultas Ekonomika dan Bisnis. Universitas Diponegoro. (https://core.ac.uk).

Rakhimsyah, L. A., \& Gunawan, B. 2011. Pengaruh Keputusan Investasi, Keputusan Pendanaan, Kebijakan Dividen Dan Tingkat Suku Bunga Terhadap Nilai Perusahaan. Jurnal Investasi Vol. 7 No.1 Juni 2011. (https://journal.trunojoyo.ac.id).

Rara Sukma Palupi, R.S., Susanto Hendiarto, S. 2018. Kebijakan Hutang, Profitabilitas Dan Kebijakan Dividen Pada Nilai Perusahaan Properti \& Real Estate. Jurnal Ecodemica, Vol. 2 No. 2 Tahun 2018. ISSN: 2355-0295,e-ISSN:2528-2255. http://ejournal.bsi.ac.id).

Rezanata Rahmanto. 2017. Pengaruh Profitabilitas, Kebijakan Utang Dan Kebijakan Dividen Terhadap Nilai Perusahaan. E- Jurnal Jurnal Ekonomi Akuntansi Vol. 3. Issue. 3. (http://fe.ubhara.ac.id).

Silalahi, Ulber. 2012. Metode Penelitian Sosial.: Penerbit PT Refika Aditama, Bandung.

Sufah dan Riduwan. 2016. Pengaruh Profitabilitas, Laverage, Ukuran Perusahaan Dan Kebijakan Dividen Pada Nilai Perusahaan di Bursa Efek Indonesia. Jurnal Ilmu dan Riset Akuntansi, Volume 5, Nomor 2. (http://jurnalmahasiswa.stiesia.ac.id). 


\section{JURNAL AKUNTANSI, Vol. 10, No. 2, November (2021)}

Sugiyono, 2017. Metode Penelitian kombinasi. Bandung, Edisi 8. Penerbit CV Alfabeta, Bandung.

Warsono, 2003. Manajemen Perusahaan, Edisi ketiga, Jilid I, Banyumedia Publishing, Malang.

Weston, Fred J dan Eugene F. Brigham, 2013. Dasar-dasar Manajemen Keuangan Jilid 1. Edisi ke-11. Jakarta: Penerbit Erlangga.

Weston, Fred J dan Copeland, Thomas E. 2010. Manajemen Keuangan Jilid 2. Jakarta: Binarupa Aksara Publisher

Wijaya, B. I., \& Sedana, I. P. 2015. Pengaruh Profitabilitas Terhadap Nilai Perusahaan (Kebijakan Dividen Dan Kesempatan Investasi Sebagai Variabel Mediasi). E-Jurnal Manajemen Unud, Vol.4, No.12, 2015: 4477-4500 ISSN:2302-8912. (https://ojs.unud.ac.id).

Website:

www.idx.co.id

https://www.sahamok.com

https://www.idcfinancials.com

https://www.cnbcindonesia.com 